\title{
Dossier Covid-19: Who is afraid of pandemics? Geographies and geopolitics of Covid-19
}

Dossier Covid-19: Who is afraid of pandemics? Geographies and geopolitics of Covid-19

Guilherme Ribeiro, Floriano José Godinho de Oliveira, Leandro Dias de Oliveira and Regina Tunes

\section{CpenEdition}

Electronic version

URL: http://journals.openedition.org/espacoeconomia/11646

DOI: 10.4000/espacoeconomia. 11646

ISSN: $2317-7837$

Publisher

Núcleo de Pesquisa Espaço \& Economia

Electronic reference

Guilherme Ribeiro, Floriano José Godinho de Oliveira, Leandro Dias de Oliveira and Regina Tunes, "Dossier Covid-19: Who is afraid of pandemics? Geographies and geopolitics of Covid-19 ", Espaço e Economia [Online], 18 | 2020, Online since 13 April 2020, connection on 24 September 2020. URL http://journals.openedition.org/espacoeconomia/11646; DOI : https://doi.org/10.4000/ espacoeconomia. 11646

This text was automatically generated on 24 September 2020 .

(c) NUPEE 


\title{
Dossier Covid-19: Who is afraid of pandemics? Geographies and geopolitics of Covid-19
}

\author{
Dossier Covid-19: Who is afraid of pandemics? Geographies and geopolitics of \\ Covid-19 \\ Guilherme Ribeiro, Floriano José Godinho de Oliveira, Leandro Dias de \\ Oliveira and Regina Tunes
}

1 When Espaço e Economia was launched in the second semester 2012, the aim of the founding editors was to enhance the field of economic geography in Brazil, as well as to provide an instrument for political and intellectual interventions on current topics.

Whether in the past or in the present, the métier of the geographer cannot separate scholarship from politics, which would result in a sterile and ideological interpretation of reality. From the choice of key notions to the publication of research results, geographyis inseparable from the political dimensions that organise the social life. To all geographers and social scientists who accepted the challenge of writing in the heat of the crisis thanks to the intellectual, affective, and political complicity that unites us, our most sincere acknowledgements.

While in Age of Extremes: 1914-1991, the great Marxist historian Eric Hobsbawm argued that the Second World War was a true lesson of world geography (Hobsbawm 1990), the spread of Covid-19 was also a very lesson to contemporary geography, in addition to reveal the terrifying face of the neoliberalism, globalization, and urban segregation.

So, the impact of neoliberalism on a global scale and its territorial consequences in a peripheral country such as Brazil represents a death threat for thousands of indigenous peoples, Afro-Brazilian communities, as well as for urban workers in the metropolitan peripheries. Following work and pensions' "reforms" - this word is deliberately inappropriate in order to mask its real meaning -implemented since 2016 by Michel Temer's and Jair Bolsonaro's governments and celebrated with enthusiasm by the 
market, the suppression of public services in the name of the privatization of life has been adopted as a norm.

Our use of the word "norm" is not accidental. It is a keyword in the comprehension of capitalism as a system obliged to create incessantly an appearance of normality but, due to its own quintessence, one which is unable to hide its contradictions - despite the fact we that are many times unable to distinguish them.

The pandemics revealed all of them.

7 If the solution to Covid-19 consists in a vaccine, what would be the solution to the virus of income concentration, exploitation of work, outrageous interests, deplorable billionaire bank profits, and to an authoritarian state that criminalizes social movements?

A full reply will not come from Biochemical, nor from Epidemiology, but from what the state has been doing with its population. If normality implies that the public health system is close to collapse, managing the medical-hospital care increase will be a hard task. If normality admits millions of houses without conditions of life, demanding special care from the peripheries sounds like an inversion of values. If normality admits wages as just even if they are whimsy, temporary suspensions of employees and government support will be automatically seen as legitimate measures aiming to overlap crisis.

By the way, what is the Leitmotiv of that crisis?

10 The present dossier is no mean our modest reaction to the research funding cuts in general and of the Humanities in particular from the Bolsonaro Government. If the relevance of the technological and innovation spheres is unquestionable in the twentyfirst century, disregarding the extent of Humanities in the comprehension of themes such as democracy, politics, citizenship, xenophobia, education, culture, ethics, religion and memory - just for mentioning some of them - means adhering to a technique and pragmatic world vision whose dangerous as fatal effect is the complete annihilation of the other.

11 The recognition of the other - of ourselves, evidently - belongs to a series of social practices established precisely on the notion of public and on the complex equilibrium between private freedom and collective guarantees. Nevertheless, in a country torn by slavery, subalternity, and authoritarianism, the rise of neoliberalism and its emphasis on individualism has built the perfect scenery to the stranglehold of the discussion about the sense of the public, the social, and the collective.

Close to itself, individualism is the shortest way to the proliferation of all kinds of dogmatism. In the name of private interests, it cultivates fear of dialogue, of pluralism, of discussion. Perhaps, this pandemics could temporarily displace its beliefs. This is one of the reasons for which public, free, and high level University symbolizes a threat to the status quo. It orbits partially out of the control and vigilance state. Certainly free thought has an action ray that goes beyond the limits of predictable. 


\section{AUTHORS}

\section{GUILHERME RIBEIRO}

PPGGEO/UFRRJ. Email: geofilos@msn.com

FLORIANO JOSÉ GODINHO DE OLIVEIRA

PPFH/UERJ. Email: fgodinhodeoliveira@gmail.com

\section{LEANDRO DIAS DE OLIVEIRA}

PPGGEO/UFRRJ. Email: ldiasufrrj@gmail.com

\section{REGINA TUNES}

IGEOG/UERJ. Email: tunesregina@gmail.com 